\title{
The Impact of Terrorism on Foreign Direct Investment in Kenya
}

\author{
Solomon Kinyanjui ${ }^{1}$ \\ ${ }^{1}$ Business Administration, School of Human Resource Development, Jomo Kenyatta University of Agriculture \& \\ Technology, Nairobi, Kenya \\ Correspondence: Solomon Kinyanjui, Business Administration, School of Human Resource Development, Jomo \\ Kenyatta University of Agriculture \& Technology, Nairobi, Kenya. E-mail: kinyanjui@solsinclinations.com \\ Received: March 28, 2014 \\ Accepted: April 29, 2014 \\ Online Published: May 6, 2014 \\ doi:10.5430/ijba.v5n3p148 \\ URL: http://dx.doi.org/10.5430/ijba.v5n3p148
}

\begin{abstract}
This paper assessed the relationship between terrorism and foreign direct investment in Kenya. Secondary data on the Terrorism attacks and FDI from 2010 to 2012 was used for the study. Multiple regression model was used to test of the relationship between the study variables. By applying the model, the study found that terrorism negatively affects FDI in Kenya. It was concluded that Terrorism activities negatively affect the FDI in Kenya. Terrorism activities decrease the foreign investor confidence, which decrease the FDI. The Null hypothesis that there is no relationship between terrorism and FDI was thus rejected.
\end{abstract}

Keywords: terrorism, foreign direct investment, casualties and injuries

\section{Introduction}

Terrorism, like civil conflicts, may cause spillover costs among neighboring countries as a terrorist campaign in a neighbor dissuades capital inflows, or a regional multiplier causes lost economic activity in the terrorism-ridden country to resonate throughout the region. In some instances, terrorism may impact specific industries as 9/11 did on airlines and tourism (Drakos, 2004). Another cost is the expensive security measures that must be instituted following large attacks such the massive homeland security outlays since 9/11 (Enders and Sandler, 2006). Terrorism also raises the costs of doing business in terms of raising the insurance premiums, increasing the costs for security precautions, and larger salaries to employees at-risk.

According to Collier et al. (2003), terrorist incidents have economic consequences by diverting foreign direct investment (FDI), destroying infrastructure, redirecting public investment funds to security, or limiting trade. Kenya as a country has lost a lot of finances in the fight against terrorism. In one of the country's effort to counter terrorism, Kenya launched military operations in neighboring Somalia against Al Shabaab. Just as capital may take flight from a country plagued by a civil war, a sufficiently intense terrorist campaign may greatly reduce capital inflows (Enders and Sandler, 1996).

In 1960s and 1970s, Kenya was a prime choice for foreign investors seeking to establish a presence in East Africa. Since 1980s, Kenya's combination of politically driven economic policies, rampant corruption, government malfeasance, substandard public services, and poor infrastructure discouraged foreign direct investment (FDI). Over the past three decades, Kenya has been a comparative under-performer in attracting FDI. Although the performance of Kenya in attracting FDI has been marginally better since the middle of the last decade, its performance still lags behind the neighbouring countries like Tanzania and Uganda in dollar terms, despite the fact that these are smaller economies.

Kenya has had its fare share of attacks including The US Embassy 1998 and the recent most devastating attack on Kenya's premier shopping mall (Westgate) on Saturday $21^{\text {st }}$ September 2013 which left 67 people dead. Economic growth may slow down with the continued terrorism threat with Somalia being in the immediate geographic proximity. Growth in the Economy slows down as attacks continue. Although studies investigating the impact of terrorism on FDI are new, they are currently gaining popularity following the devastating events in the United States on Sept. 11, 2001. Shahbaz et al. (2013) did a study on the impact of terrorism on Foreign Direct Investment in Pakistan. They found that due to increase in the number of terrorist attacks foreign investor showing negative interest to invest money in Pakistan. This study therefore focuses on the Effect of terrorism on FDI in Kenya. 


\subsection{Problem Statement}

It has been documented that the direct impact of terrorist attacks on productive capital is relatively modest. This seems to be true even for events of catastrophic terrorism. For example, Becker and Murphy (2001) estimated that the September 11th terrorist attacks resulted in a loss of $0.06 \%$ of the total productive assets of the US economy. Some authors have argued that terrorism is unlikely to exert a significant influence on economic activity in the long run. The calculations in Becker and Murphy (2001) bound the long-run effect of the September 11th attacks to 0.3\% of GDP (IMF, 2001 and OECD, 2001).

Kenya as a third world economy is struggling with the effects of terrorism. The nation has suffered several attacks over the last few years beginning to the 1998 US Embassy bombings to the latest Westgate attack. On September 21, 2013, masked gunmen attacked the upscale Westgate shopping mall in Nairobi, Kenya, taking hostages and killing at least 67 people (Note 1). Almost 200 people, including at least 5 U.S. citizens, were wounded in the siege that took four days. The attack is the most deadly terrorist incident in Kenya since the 1998 Al Qaeda bombing of the U.S. Embassy in Nairobi (Note 2). A Somali Islamist group, Al Shabaab having ties to Al Qaeda has claimed responsibility for the Westgate attack. It is therefore without doubt that the attacks have in one way of the other affected the Kenyan economy. This paper therefore seeks to determine the effect of terrorism of FDI in Kenya.

\subsection{Objective of the Study}

The main objective of this study is to determine the impact of Terrorism of FDI in Kenya.

\section{Literature Review}

This section presents relevant literature of the Effect of terrorism on the FDI and the trends of FDI in Kenya.

\subsection{Impact of Terrorism of FDI}

It is obvious that the losses of human life and suffering in the aftermath of a terrorist attack can be tremendous and maybe even considered as an economic loss particularly in today's society where numbers count. This study, however, aims only at the impact of terrorism expressed in terms of FDI.

The conceptualization and the calculation of economic costs of terrorism differ widely. Nevertheless, common ground that the criteria of economic costs comprise four major dimensions exists (Looney, 2002). Those dimensions distinguish costs according to their nature, time period, impact and geographical range of impact. Another dimension that is sometimes added is the differentiation in targets of attacks. Jackson et al (2007: 22) distinguish in this regard between government, businesses and individuals. This distinction is, however, not mutually exclusive. Macro- and microeconomic cost effects need to be considered both in the short and long run and a differentiation between direct and indirect are taken into account. Additionally, both can include domestic as well as transnational effects.

The last dimension that is used in academic literature refers to the distinction of costs in macroeconomic or sectoral economic realms (Sandler and Enders, 2008: 21). The main distinction between macro- and sectoral economic vulnerabilities is that the former relates to aggregate activities while the latter corresponds to sectoral activities (Ibid: 34). Macroeconomic costs are regarded as costs that have an impact on the overall national economy and can best be measured by indicators such as the GDP, FDI, exchange rates and imports/exports. Microeconomic or sectoral costs, in contrast, correspond to welfare losses for certain sectors in a country, such as transport, energy and telecommunication. This study will focus on the impact of terrorism on FDI.

The focus of this study is on both direct and indirect effects of terrorism on the macro economy and macroeconomic sectors. The direct impact of terrorist assaults can be determined relatively easily by summing up the costs of the material damage following an attack. Indirect effects are in contrast often hard to measure: 'Estimates of the costs of terror confront problems of different types, including the measurement of losses, aggregation issues, avoidance of double counting of damages in different sectors or statistics, and the causality of second round and indirect effects' (Bruck and Wickstrom, 2004: 294). To circumvent the problems, various economic events have been used to specify indirect effect. The following events appear most frequently (Haj-Yehia, 2006: Frey et al, 2007: 2, DNB, 2005: 50): Uncertainty on financial markets diverts foreign resources away from the affected country and leads to a linked effect on stock markets; fear of terrorist attacks induces additional government spending on counterterrorism programs often making trade more expensive by a rise in transaction costs; fear of attacks additionally leads to a cutback of individual consumption causing an effect on private allocation by a shift of resources and uncertainty on financial markets causes a reduction of investment and a related decrease of the overall economic performance.

From these events one can derive four central macroeconomic indicators, which cover, in particular, investment and consumption rates, the ratio of public spending for counterterrorism and defense purposes, export and import figures 
and GDP. GDP is even considered to be an indicator of the status of an economy. It is necessary to point out that the key indicators described above are not exhaustive. Other indicators are, for instance, the effect of terrorism on exchange rates resulting from distrust in terrorism affected currency or effects on consumer sentiment, inflation, unemployment levels and interest rates (Morag, 2006; Major, 2003: 3). This study only covers the first four, i.e. GDP, investment, consumption and trade, as they are the most widely used indicators of calculating the impact of crisis in general and terrorism specifically (Haj-Yehia, 2006: Frey et al, 2007: DNB, 2005).

A study presented in a seminar organized by Crotian National Bank empirically investigated how international terrorism and institutional factors affecting foreign direct investment (FDI) outflows from rich countries. He employed a sample of 23 FDI sending countries in the period from 1995 to 2010, and used the sample selection correction method to address the missing observations problem. The findings revealed that on average, if FDI host country increases the number of terrorist attacks towards investor by one standard deviation, there is a decrease in the flow of investment by 14 percent of the average FDI share in a host's GDP. The findings also revealed that that if one investor experiences an attack, other investors suffer from a negative spillover effect. Finally, the study revealed that that in the last 16 years by the time of the study, perceived political stability is the most important factor for FDI investments (The Eight Young Economists Seminar, 2013).

Persitz (2005) evaluated the effect of Palestinian terror on the Israeli economy by using counterfactual methodology and quarterly data for the macroeconomic aggregates of Israel and OECD countries from 1980 to 2003. He found that, since 1994, had there been no terror in Israel, the country's per-capita GDP in 2003 would have been $8.6 \%$ higher than it was. Predictions based on low future levels of terror and the absence of a peace process produced good out-of-sample fit for 2003-2005. Palestinian terror increased the shares of government expenditures and consumption and decreased the shares of trade balance and investment in GDP. Also observed was weak evidence of a structural change at the aggregate level.

Shahbaz et al. (2012) did a study to examine the relationship between terrorism and foreign direct investment. They used data from 2000 to 2011, the ordinary least square testing approach is used to examine the relationship in two variables. This methodology was used to check the linearity and normality of the data. By applying the model, they found that terrorism has significant negative effect on foreign direct investment of Pakistan. The findings revealed that due to increase in the number of terrorist attacks, foreign investors showed negative interest to invest money in Pakistan.

The amounts of FDI in the US before and after the September 11th attacks provide some suggestive evidence of the open-economy channel of terrorism. In the year 2000, the year before the terrorist attacks, FDI inflows represented about $15.8 \%$ of the Gross Fixed Capital Formation in the US. This figure decreased to only 1.5\% in 2003, two years after the attacks. Conversely, FDI outflows from the US increased from about $7.2 \%$ of the Gross Fixed Capital Formation for the US in 2000 to $7.5 \%$ in 2003 (UNCTAD, 2004).

Of course, not all this variation in FDI can be attributed to the effect of the September 11th attacks. As of September 2001 FDI inflows had fallen from its 2000 peak not only in the US but also in other developed economies (UNCTAD, 2002). These figures motivate the question of the extent to which an increase in the perceived level of terrorism was responsible for the drop in FDI in the US that followed the events of September 11th. Surveys of international corporate investors provide direct evidence of the importance of terrorism on foreign investment. Terrorism is rated by corporate investors as one of the most important factors influencing their FDI decisions (Global Business Policy Council, 2004).

\subsection{Trends in Foreign Direct Investment (FDI) Statistics in Kenya}

Through the 80's and 90's, the deterioration in economic performance, together with rising problems of poor infrastructure, corruption, high cost of borrowing, crime and insecurity, and lack of investor confidence in reforms generated a long period of low FDI inflow. However, net inflows increased more than fourteen fold between 2006 and 2007, from US\$51 million ( $0.2 \%$ of GDP) in 2006 to a record US\$729 million (2.7\%) in 2007, according to the World Bank's World Development Indicators. FDI inflows dropped off sharply in 2008, coming in at only US\$96 million $(0.3 \%)$, and then increased to US\$116 million (0.4\%) in 2009 and US\$186 million $(0.6 \%)$ in 2010 . These figures compare poorly to neighboring Tanzania and Uganda, which have both posted higher net FDI inflows in dollar terms than Kenya each year since 2005, with the exception of 2007, despite their smaller economies. In 2010, Tanzania reported US\$433 million in net FDI inflows and Uganda reported US\$817 million (KPMG, 2012).

Despite its potential, Kenya is still not attracting adequate long-term capital inflows to power its growth. Kenya receives less long-term capital inflows than any other country in the EAC region. According to CBK balance of 
payment data, official medium and long terms flows, which are mainly project loans (including defense loans), increased from US\$ 527 million in 2010, to US\$ 612 million in 2011, and then to US\$ 1,449 million in 2012. However, foreign direct investment (FDI) remained subdued, as Kenya received only US\$ 177 million (2010), US\$ 140 million (2011) and US\$ 164 million (2012) according to CBK data.

UNCTAD data on the other hand shows that Kenya received US\$ 178.1 million (2010) and US\$ 335 million (2011) in FDI. Kenya's performance in attracting foreign investment remains limited compared to its peers. The FDI Kenya attracted was only equivalent to 0.8 percent of its GDP in 2010-11, compared to Rwanda (1.2 percent of GDP), Tanzania (2.8 percent of GDP), and Uganda (6.2 percent of GDP) in the same period (see Figure 1.24). However, following the recent peaceful elections, and given the improvements in the governance framework since the new Constitution was adopted in 2010, FDI to Kenya is expected to increase in the future.

In Kenya, the stock of Foreign Liabilities increased by $26.3 \%$ from KSh 340,128 million in 2007 to KSh 429,585 million in 2008 with FDI accounting for $63.8 \%$ of the total liabilities at KSh 274,004 million. Analysis of external liabilities stock by the regional economic blocs reveal that Europe accounted for $69.7 \%$ of the total liabilities with the European Union accounting for $67.1 \%$. America, Asia and Africa accounted for $18.5 \%, 6.2 \%$ and $5.6 \%$, respectively. The stock of Foreign Liabilities from China and India more than doubled over the period. Manufacturing followed by Information and Communication and Financial and Insurance Sectors had the highest stock of FDI liabilities in 2008 (KNBS, 2013)

Kenyan foreign capital inflows in 2008 totaled KSh 92,253 million compared to KSh 110,480 million recorded in 2007. The $16.5 \%$ decline in the inflows may be partly attributable to post election violence and the negative effects of global economic and financial crisis in 2008. The inflows were mainly in the form of debt instruments and Foreign Direct Investment, which accounted for $51.4 \%$ and $26.4 \%$ of the total inflows respectively. The findings indicate that, Netherlands, France, India, Japan and United Kingdom are the main sources of foreign private capital inflows. Information and Communication, Manufacturing and Financial and Insurance sectors were the leading beneficiaries of FDI inflows (KNBS, 2013).

Total outflows of foreign liabilities increased by $26.8 \%$ from KSh 27,992 million in 2007 to KSh 38,799 million in 2008 with the highest being trade credits. Outflows of Direct Investment and Other Investment accounted for 70.8\% and $29.0 \%$ respectively, in 2008. The major destinations of FDI outflows in 2008 were US, France, United Kingdom and Germany jointly accounting for $72.1 \%$ of the total outflows (KNBS, 2013).

The stock of external assets stood at KSh 41, 935 million in 2008 compared to KSh 64,555 in 2007 a decline of $35.0 \%$. The reduction in assets was as a result of reductions in loan advances abroad. The major investment destinations for Kenyan enterprises were Uganda, Tanzania and United Kingdom (KNBS, 2013).

The tax regime, particularly tax administration; insecurity and corruption; cost and efficiency of road and inland transport; cost and supply of electricity had a significant negative effect on operation of businesses. Survey results also revealed that interest rates, exchange rate and inflation rate were perceived to have a net negative effect on investment decisions. However, access to international markets; internal finance and regional finance was perceived to have a net positive effect. This suggests that apart from the domestic market investors place great importance on international markets still. The survey findings indicated that both telecommunication and internet use had a significant impact on investment decisions (KNBS, 2013).

Enterprises reported that they were likely to increase the range of products and services, staff training, recruitment of local staff, investment in technology, export of the products and improvement of existing facilities in the medium term. Those who planned to expand investment in technology comprised $78.1 \%$ of the respondents while those intending to improve existing facilities and staff training was $72.9 \%$ and $72.8 \%$ of the enterprises, respectively. More than half of the enterprises plan to expand their businesses in the next three years (KNBS, 2013).

A variety of factors explain low FDI in Kenya (i) infrastructure bottlenecks both in energy and roads have been a major constraint on FDI, (ii) Kenya's labor productivity has been falling in the recent past, while at the same time, labour costs have been rising fast compared to their productivity and (iii) The regulatory environment in Kenya has been hostile to FDI and impeded it. Excessive regulations have hindered entrepreneurial activity, as firms spend more time and resources complying with rules and regulations. This study focuses on the effect of Terrorism of FDI in Kenya. Table 1 below shows the FDI in Kenya from 1998 to 2012. 
Table 1. FDI in Kenya from 1998 to 2012

\begin{tabular}{|c|c|c|c|c|c|c|c|c|c|c|c|c|c|c|c|}
\hline \multicolumn{16}{|l|}{ Year } \\
\hline & 1998 & 1999 & 2000 & 2001 & 2002 & 2003 & 2004 & 2005 & 2006 & 2007 & 2008 & 2009 & 2010 & 2011 & 2012 \\
\hline \multicolumn{16}{|l|}{ FDI in } \\
\hline \multicolumn{16}{|l|}{ Millions } \\
\hline USD & 807 & 821 & 932 & 937 & 965 & 1,046 & 1,092 & 1,114 & 1,164 & 1,893 & 1,989 & 2,104 & 2,282 & 2,617 & 2,876 \\
\hline Increase & 11 & 14 & 111 & 5 & 28 & 81 & 46 & 22 & 50 & 729 & 96 & 115 & 178 & 335 & 259 \\
\hline \multicolumn{16}{|l|}{$\%$} \\
\hline Increase & 1.36 & 1.71 & 11.91 & 0.53 & 2.9 & 7.74 & 4.21 & 1.97 & 4.3 & 38.51 & 4.83 & 5.47 & 7.8 & 12.8 & 9.01 \\
\hline
\end{tabular}

Source: UNCTAD website.

\section{Methodology}

Dependent variable of this study is foreign direct investment (FDI) in Kenya and Independent variable is terrorism. FDI is measured by Net inflow of foreign direct investment in USD and Terrorism is measured by No of terrorist attacks in Kenya. Sample of this study, which is used to evaluate relationship, is from 2010-2012, which consists of three years. Secondary data is used to conclude results on the basis of finding of study. Data of terrorist attacks is collected from different sources such as Nation Media reports and foreign direct investment data is collected from UNCTAD website.

Null and alternative hypothesis of this research study are:

Ho: There is no relationship between terrorism and foreign direct investment in Kenya

$\mathrm{H} 1$ : There is a relationship between terrorism and foreign direct investment in Kenya

Multiple regression model presented below was used to test on the relationship between the variables of the study:

$\mathrm{Y}=\mathrm{a}+\beta_{1} \mathrm{X}_{1}+\varepsilon$

Where:

$$
\begin{aligned}
\mathrm{Y} & =\text { FDI } \\
\mathrm{X}_{1} & =\text { Terrorism } \\
\mathrm{a} & =\text { Constant } \\
\varepsilon & =\text { Error Term }
\end{aligned}
$$

\section{Data}

Terrorism attacks, deaths, FDI in Kenya from 2010 to 2013

\begin{tabular}{cccccc}
\hline Year & No. of attacks & Casualties/Deaths & Injuries & FDI & \% increase in FDI \\
\hline 2010 & 3 & 10 & 56 & 2,282 & $7.8 \%$ \\
\hline 2011 & 13 & 14 & 71 & 2,617 & $12.8 \%$ \\
\hline 2012 & 25 & 60 & 308 & 2,876 & $9.01 \%$ \\
\hline 2013 & 15 & 93 & 274 & - & - \\
\hline
\end{tabular}




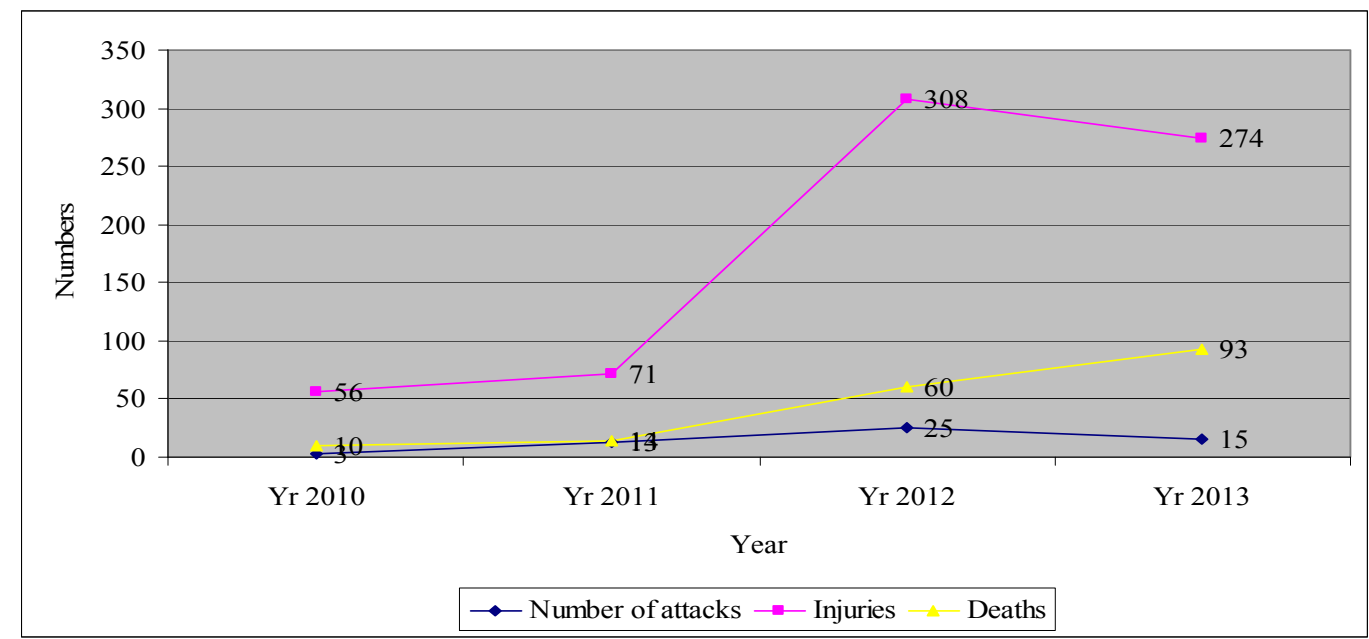

Graphical presentation of Terrorism attacks, casualties and deaths in Kenya from 2010 to 2013

Terrorism attacks and Foreign Direct Investments in Kenya from 2010 to 2012

\begin{tabular}{lccc}
\hline Year & 2010 & 2011 & 2012 \\
\hline FDI in Millions USD & 2,282 & 2,617 & 2,876 \\
\hline Percentage increase in FDI & $7.8 \%$ & $12.8 \%$ & $9.01 \%$ \\
\hline Number of attacks & 3 & 13 & 25 \\
\hline
\end{tabular}

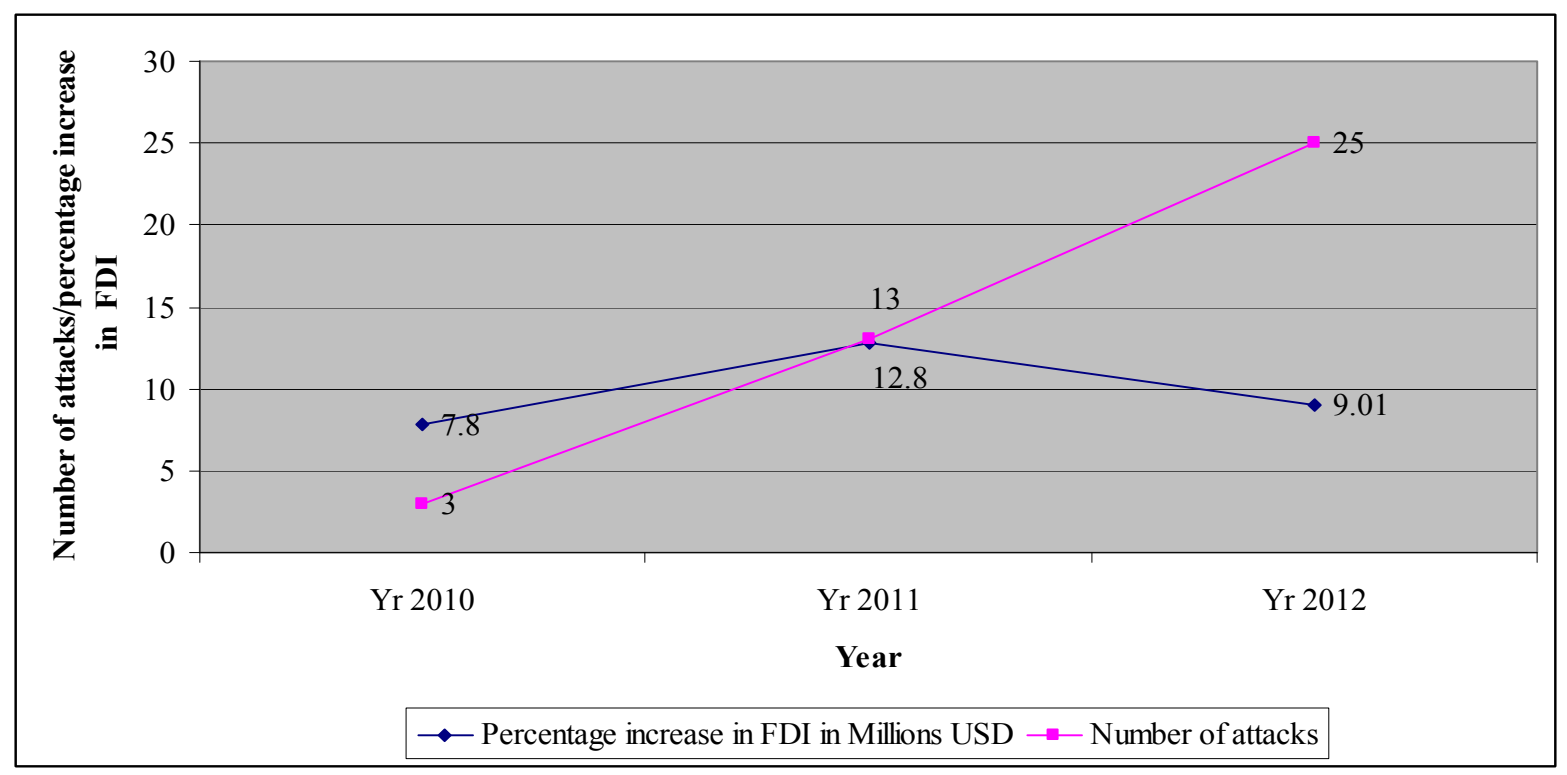

Graphical presentation of terrorism attacks and percentage increase in Foreign Direct Investments in Kenya from 2010 to 2012

\section{Hypothesis Testing}

This research paper tested the normality and linearity of time series data used in study. Multiple regression model presented below was used to test on the relationship between the variables of the study:

$\mathrm{Y}=\mathrm{a}+\beta_{1} \mathrm{X}_{1}+\varepsilon$

Where: 


$$
\begin{array}{ll}
\mathrm{Y} & =\text { FDI } \\
\mathrm{X}_{1} & =\text { Terrorism } \\
\mathrm{a} & =\text { Constant } \\
\varepsilon & =\text { Error Term }
\end{array}
$$

Table 2. Model summary

\begin{tabular}{lllll}
\hline Model & R & R Square & $\begin{array}{l}\text { Adjusted R } \\
\text { Square }\end{array}$ & $\begin{array}{l}\text { Std Error of the } \\
\text { Estimate }\end{array}$ \\
\hline $\mathbf{1}$ & 0.992051 & 0.984164 & 0.968329 & 1.960299 \\
\hline
\end{tabular}

The R Squared shows that the independent variable (terrorism attack) explains 98.4 percent of the variance in the FDI. Adjusted R squared attempts to correct R squared to more closely reflect the goodness of fit of the model. Use

\begin{tabular}{|c|c|c|c|c|c|}
\hline Model & $\mathrm{df}$ & Sum of Squares & $\begin{array}{l}\text { Mean } \\
\text { Square }\end{array}$ & $\mathrm{F}$ & Significance \\
\hline Regression & 1 & 238.8239 & 238.8239 & 62.14887 & 0.008 \\
\hline Residual & 1 & 3.842771 & 3.842771 & & \\
\hline Total & 2 & 242.6667 & & & \\
\hline
\end{tabular}
of R Squared helps in determining the model of best fit. The results suggest that terrorism significantly affect FDI (at the 95 percent confidence level).

ANOVA

a. Predictors: (Constant), Terrorism

b. Dependent Variable: FDI

The regression results show that the significance value ( $p$-value) of $\mathrm{F}$ statistics is less than 0.05 (it is actually 0.008 ). This implies that the independent variable (terrorism) explain the variation in the dependent variable (FDI).

Coefficients

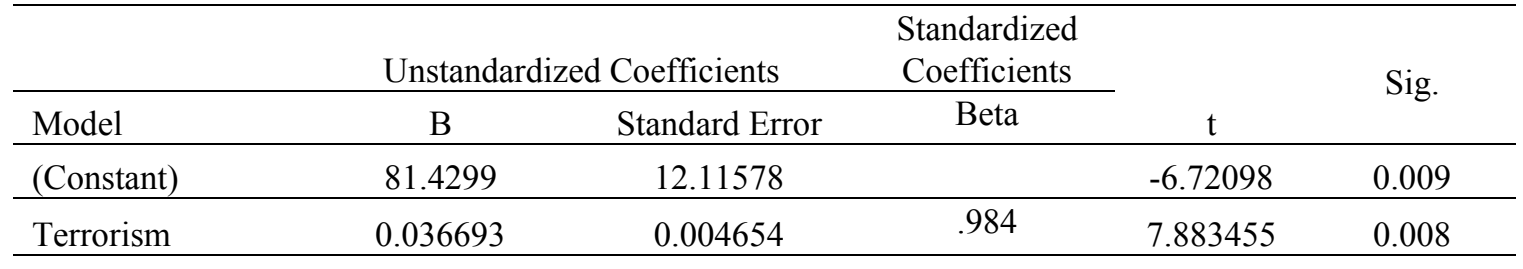

a. Dependent Variable: FDI

The Beta Coefficients in the regression show that terrorism has positive relationship with FDI provided by coefficient value of .984 . The findings show terrorism is statistically significant with p-values less than 0.05 .

\section{Conclusions}

From the findings of the study, it can be concluded that Terrorism activities negatively affect the FDI in Kenya. Terrorism activities decrease the foreign investor confidence, which decrease the FDI. The Null hypothesis that there is no relationship between terrorism and FDI is rejected. These findings are inline with the findings of a study presented at the Eight Young Economists Seminar (2013) where they found that on average, if FDI host country increases the number of terrorist attacks towards investor by one standard deviation, there is a decrease in the flow of investment by 14 percent of the average FDI share in a host's GDP. The findings also revealed that that if one investor experiences an attack, other investors suffer from a negative spillover effect. Finally, the study revealed that that in the last 16 years by the time of the study perceived political stability is the most important factor for FDI 
investments. The findings are also supported by Shahbaz et al. (2012) study examining the relationship between terrorism and foreign direct investment where they found that due to increase in the number of terrorist attacks, foreign investors showed negative interest to invest money in Pakistan.

\section{Acknowledgement}

I wish to acknowledge advice and directions by Dr. Margaret Oloko, Dr. Hazel Gachunga \& Dr. Beatrice Gathondu of Jomo Kenyatta University of Agriculture \& Technology.

\section{References}

Becker, G., \& Murphy, K. (2001). Prosperity will rise out of the ashes. Wall Street Journal, October 29.

Bruck K., \& Wickstrom, P. (2004). The Economic Consequences of Terror. European Journal of Political Economy, 20(2), 293-300.

Collier, P., Elliott, E., Hegre, H., Reynal-Querol, M., \& Sambanis, N. (2003). Breaking the Conflict Trap: Civil War and Development Policy. Washington: World Bank.

DNB (De Nederlandsche Bank). (2005). Terrorisme: beperkte gevolgen voor de economie. Kwartaalbericht September, pp. 50-57

Drakos, K. (2004). Terrorism-induced structural shifts in financial risk: airline stocks in the aftermath of the September $11^{\text {th }}$ terror attacks. European Journal of Political Economy, 20, 349-366.

Enders, W., \& Sandler, T. (1996). Terrorism and Foreign Direct Investment in Spain and Greece. Kyklos, 49, 331-52.

Enders, W., \& Sandler, T. (2006). The Political Economy of Terrorism. Cambridge University Press, Cambridge.

Frey, B.S., S. Luechinger, \& A. Stutzer. (2007). Calculating Tragedy: Assessing the costs of Terrorism. Journal of Economic Surveys, 21(1), 1-24.

Global Business Policy Council. (2004). FDI Confidence Index. A.T. Kearney, Alexandria, VA.

Haj-Yehia, S. (2006). Terrorizing Consumers and Investors. January 2006.

IMF. (2001a). How has September 11 influenced the global economy? World Economic Outlook.

Jackson, Brian A., L. Dixon, \& V.A. Greenfield. (2007). Economically Targeted Terrorism, A Review of the Literature and a Framework for Considering Defensive Approaches, Santa Monica. RAND Corporation Kenya Foreign Investment Survey 2010.

Looney, R. (2002). Economic Costs to the United States Stemming From the 9/11 Attacks. Strategic Insights, 1(6).

Major, D.V. (2003). Economic Effects of Terrorism. The Case of the US/Global Economy Post 9-11. Master thesis, Berlin.

Morag, N. (2006, September). The economic and social effects of intensive terrorism: Israel 2000-2004. Middle East Review of International Affairs, 10(3).

OECD. (2001). Organisation for economic co-operation and development. Economic Outlook, 71.

Persitz, D. (2005). The Economic Effects of Terrorism: Counterfactual Analysis of the Case of Israel.

Sandler, T., \& Enders, W. (2008). Economic Consequences of Terrorism in Developed and Developing Countries: An Overview. In P. Keefer and N. Loayza (Eds.), Terrorism and Economic Development (pp. 17-47). Cambridge, Cambridge University Press.

Shahbaz, M.A, Javed, A., Dar, A., \& Sattar, T. (2012). Impact of Terrorism on Foreign Direct Investment in Pakistan. Archives of Business Research, 1(1).

UNCTAD. (2004). United Nations Conference on Trade and Development. Foreign investment database. Retrieved from hhttp://www.unctad.org

\section{Notes}

Note 1. There are conflicting reports about the number killed in the attack, since part of the mall collapsed due to a fire that started during the siege. A final casualty count is unavailable pending recovery operations and forensic investigations.

Note 2. More than 4,000 people were injured and 218 killed, including 12 Americans, in the 1998 embassy bombing. 


\section{Appendices}

Appendix I. Graphical presentation of FDI from 1998 to 2012

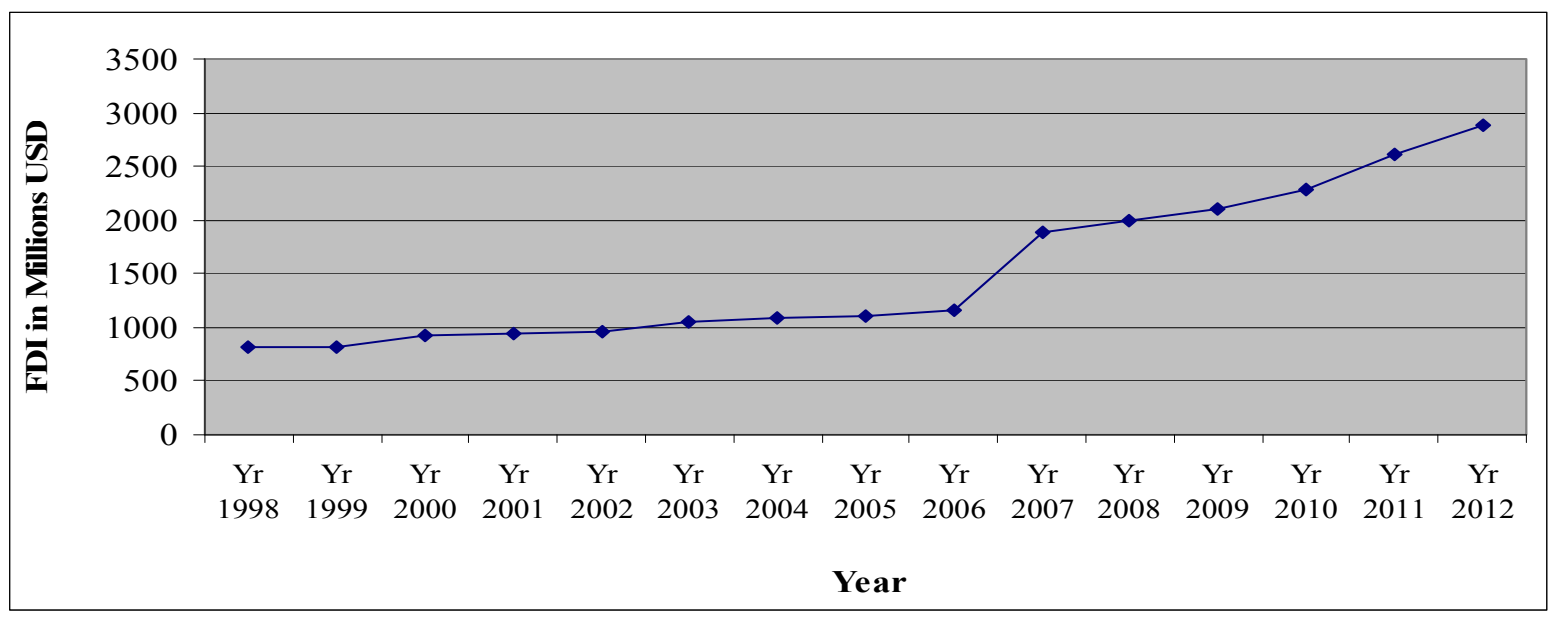

Graphical presentation of Percentage increase in FDI from 1998 to 2012

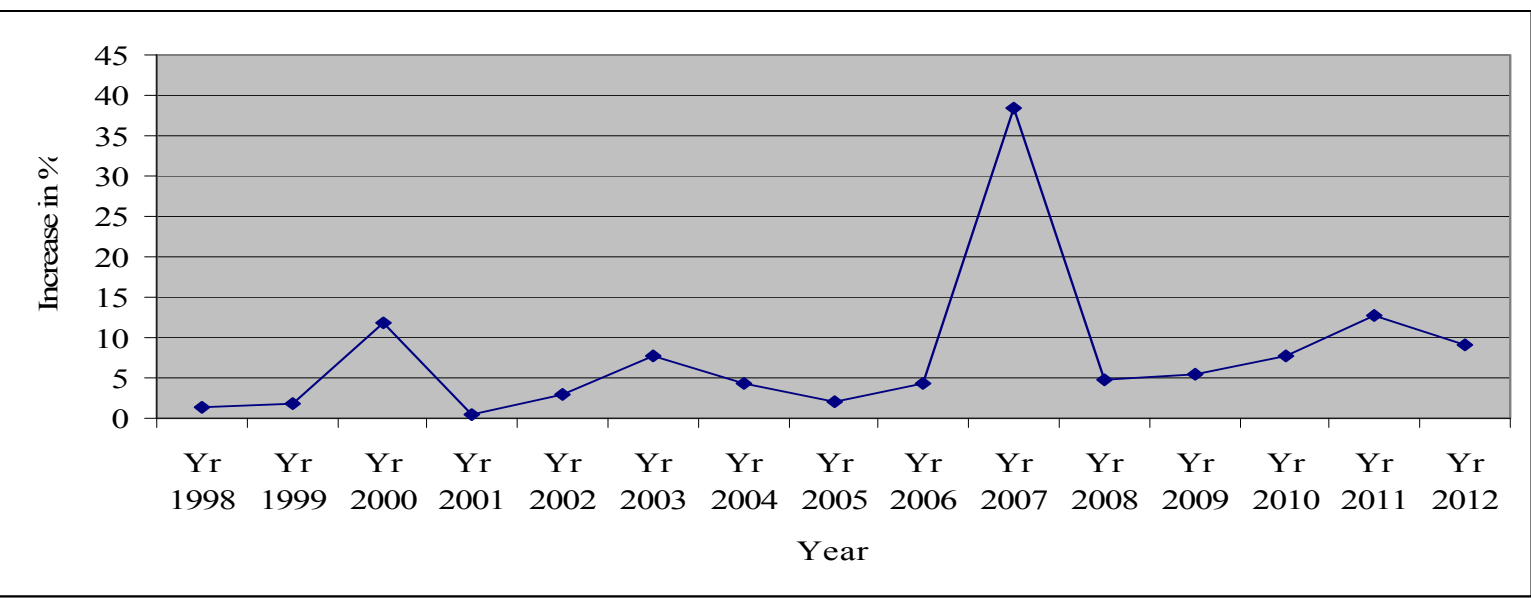

Appendix II. Terrorism attacks in Kenya

\begin{tabular}{lccc}
\hline Date/YEAR & Nature of Attack & Injuries & Casualties/Deaths \\
\hline March 1, 1975 & Bomb Blast & 35 & 27 \\
\hline Dec 31, 1980 & Explosion & 85 & 22 \\
\hline August 7, 1998 & Bomb Blast & Many injured & 224 \\
\hline Nov 28,2002 & Bomb Blast & 80 & 15 \\
\hline June, 11, 2007 & Explosion & 0 & 2 \\
\hline Before 1998 & $\mathbf{5}$ & $\mathbf{2 0 0}$ & $\mathbf{2 9 0}$ \\
\hline $16^{\text {th }}$ June, 2010 & Grenade attack & 30 & 6 \\
\hline $4^{\text {th }}$ Dec, 2010 & Grenade attack & 0 & 3 \\
\hline $20^{\text {th }}$ Dec 2010 & Grenade Attack & 26 & 1 \\
\hline Total for 2010 & $\mathbf{3}$ & $\mathbf{5 6}$ & $\mathbf{1 0}$ \\
\hline October 17, 2011 & Grenade attack & 15 & 1 \\
\hline Oct 24, 2011 & Grenade attack & 28 & 2 \\
\hline Nov 5, 2011 & Grenade attack & 5 & 4 \\
\hline Nov 24, 2011 & Bomb blast & 0 & 3 \\
\hline Nov 24, 2011 & Grenade attack & 0 & \\
\hline
\end{tabular}




\begin{tabular}{|c|c|c|c|}
\hline Nov 24, 2011 & Bomb blast & 3 & 1 \\
\hline Dec 5, 2011 & Bomb blast & 3 & 1 \\
\hline Dec 11,2011 & Explosions & 2 & 1 \\
\hline Dec 11, 2011 & Explosions & 9 & 0 \\
\hline Dec 12, 2011 & Explosions & 2 & 0 \\
\hline Dec 15,2011 & Twin Grenade attacks & 2 & 0 \\
\hline Dec 19, 2011 & Gun attack & 2 & 0 \\
\hline Totals for 2011 & 13 & 71 & 14 \\
\hline Jan 1,2012 & Bullets Blast & 0 & 6 \\
\hline Jan 11,2012 & Bomb blast & 0 & 10 \\
\hline Mar 10, 2012 & Explosions & 63 & 6 \\
\hline Mar 31,2012 & Bomb blast & 33 & 1 \\
\hline April 29,2012 & Grenade attack & 10 & 1 \\
\hline May 15,2012 & Grenade attack & 6 & 1 \\
\hline May 15,2012 & Grenade attack & 4 & 1 \\
\hline May 28,2012 & Explosion & 36 & 1 \\
\hline June 2,2012 & Petrol bomb & 0 & 0 \\
\hline June 24,2012 & Explosion & 30 & 4 \\
\hline July 1,2012 & Grenade attack & 66 & 17 \\
\hline July 19,2012 & Blast & 0 & 0 \\
\hline Aug 27,2012 & Gun attack & 0 & 1 \\
\hline Aug 28,2012 & Grenade attack & 0 & 1 \\
\hline Aug 29,2012 & Grenade attack & 4 & 2 \\
\hline Sept 30,2012 & Explosive device & 0 & 1 \\
\hline Oct 17,2012 & Grenade attack & 8 & 1 \\
\hline Nov 4, 2012 & Grenade attack & 10 & 1 \\
\hline Nov 6,2012 & Explosive device & 2 & 0 \\
\hline Nov 16,2012 & Grenade & 3 & 0 \\
\hline Dec 3,2012 & Petrol bomb & 1 & 0 \\
\hline Dec 5,2012 & Explosive & 8 & 0 \\
\hline Dec 7,2012 & Grenade attack & 1 & 2 \\
\hline Dec 16,2012 & Explosion & 1 & 0 \\
\hline Dec 20,2012 & Gun attack & 1 & 3 \\
\hline Totals for 2012 & 25 & 308 & 60 \\
\hline Jan 1, 2013 & Grenade attack & 3 & 0 \\
\hline $\operatorname{Jan} 4,2013$ & Grenade attack & 7 & 2 \\
\hline $\operatorname{Jan} 7,2013$ & Grenade attack & 8 & 1 \\
\hline $\operatorname{Jan} 9,2013$ & Grenade attack & 0 & 0 \\
\hline Jan 16,2013 & Gun attack & 3 & 5 \\
\hline Jan 17,2013 & Explosion & 0 & 2 \\
\hline Jan, 312013 & Explosion & 3 & 0 \\
\hline Feb,2, 2013 & Grenade attack & 2 & 0 \\
\hline Feb, 5 & Gun attack & 0 & 1 \\
\hline April 18,2013 & Gun attack & Several injured & 10 \\
\hline May 19,2013 & Grenade attack & 6 & 0 \\
\hline June 10,2013 & Explosive device & 6 & 0 \\
\hline Sept, 21, 2013 & Gun attack & 200 & 67 \\
\hline Dec 13, 2013 & Explosion & 3 & 1 \\
\hline Dec, 14,2013 & Grenade & 36 & 4 \\
\hline Totals for 2013 & 15 & 274 & 93 \\
\hline
\end{tabular}

